\section{SPRU}

Science and Technology

Policy Research
Working Paper Series

SWPS 2013-12

November, 2013

\title{
Investing in Food Security? \\ Philanthrocapitalism, Biotechnology and \\ Development
}

Sally Brooks 


\section{SPRU Working Paper Series}

The SPRU Working Paper Series aims to accelerate the public availability of the research undertaken by SPRU-associated people of all categories, and exceptionally, other research that is of considerable interest within SPRU. It presents research results that in whole or part are suitable for submission to a refereed journal, to a sponsor, to a major conference or to the editor of a book. Our intention is to provide access to early copies of SPRU research.

\section{Editors}

Tommaso Ciarli

Daniele Rotolo

\section{Associate Editors}

Florian Kern

Paul Nightingale

Matias Ramirez

Joe Tidd \&

Carlos Sato

Maria Savona \&

Mariana Mazzucato

Andrew Stirling Transitions

Caitriona McLeish

Civil military interface

Area

Energy

\section{Contact}

T.Ciarli@sussex.ac.uk

D.Rotolo@sussex.ac.uk

F.Kern@sussex.ac.uk

P.Nightingale@sussex.ac.uk

Matias.Ramirez@sussex.ac.uk

J.Tidd@sussex.ac.uk

C.E.Y.Sato@sussex.ac.uk

M.Savona@sussex.ac.uk

M.Mazzucato@sussex.ac.uk

A.C.Stirling@sussex.ac.uk

C.A.McLeish@sussex.ac.uk

J.Lieu@sussex.ac.uk

Administrator

Jenny Lieu

\section{Disclaimer}

The works available here are the responsibility of the individual author(s) and do not necessarily represent the views of other SPRU researchers. As matters of policy and practice, SPRU does not endorse individual research contributions.

\section{Guidelines for authors}

Papers shall be submitted in pdf or Word format. They should contain a title, an abstract, and keywords. Papers should be submitted to one of the Editors, who will process them and send them to the appropriate Associate Editor. Two members of SPRU will be asked to provide a short written review within three weeks. The revised versions of the paper, together with a reply to the reviewers, should be sent to the Associate Editor, who will propose to the Editors its publication on the series. When submitting the authors should indicate if the paper has already undergone peerreviewing, in which case the Associate Editors may decide to skip internal review process.

\section{Website}

SWPS: www.sussex.ac.uk/spru/research/sewps

IDEAS: ideas.repec.org/s/sru/ssewps.html 


\title{
Investing in Food Security?
}

\section{Philanthrocapitalism, Biotechnology and Development ${ }^{1}$}

\author{
Sally Brooks
}

\begin{abstract}
This paper traces the evolution of philanthropic involvement in developing country agriculture from the 'scientific philanthropy' of the Rockefeller Foundation during and after the Green Revolution era to the 'philathrocapitalism' of the Bill and Melinda Gates Foundation, by examining two cases of 'pro-poor' agricultural biotechnology research: pro-Vitamin A-enriched 'Golden Rice' and drought tolerant maize. In each case, novel institutions developed for technology transfer have created conditions conducive to future capitalist accumulation in ways that are not immediately obvious. These initiatives can be understood as institutional experiments that are shifting debates about the governance and regulation of genetically modified ('GM') crops. Meanwhile an emphasis on silver bullet solutions and institutions that 'connect to the market' diverts attention from more context-responsive approaches. This trend is likely to intensify with the announcement at the recent G8 summit backing a 'New Alliance for Food Security and Nutrition' in which agri-business corporations are to play a key role.
\end{abstract}

\section{Introduction - philanthropy, biotechnology, development}

The relationship between US-based philanthropic foundations and developing country agriculture has a seventy-year history. In 1943 the Rockefeller Foundation facilitated a US-Mexico agricultural development co-operation programme, which would later become the template for an international network of international agricultural research centres known today as the CGIAR (Consultative Group on International Agricultural Research ${ }^{2}$ ) system (Perkins, 1997). However, it was with the creation of crop research centres such as the International Rice Research Institute (IRRI) and International Maize and Wheat Improvement Centre (CIMMYT) in the 1960s, that an intervention model - which identified increased production, or yield, as the overriding goal and genetics-led crop improvement as the solution - became firmly established (Anderson et al, 1991).

The mode of overseas development assistance pioneered by the Rockefeller and Ford Foundations during the 'Green Revolution' era continued in the tradition of 'scientific philanthropy', which sets

\footnotetext{
1 This paper is a pre-publication version of Brooks, S. (forthcoming) Philanthrocapitalism, 'pro-poor' agricultural biotechnology and development, in B. Morvaridi (Ed.) New Philanthropy and Social Justice, Policy Press: Bristol.

${ }^{2}$ This term more accurately refers to the donor group that supports the network of research institutions. However in everyday parlance 'the CGIAR' and 'the CGIAR system' refers to the network of research centres.
} 
out to address 'causes' rather than symptoms of poverty -, as long as these can be addressed by science or education rather than major structural or societal change (Carnegie, 1889). Against the backdrop of the Cold War, for the US Government and its allies the core aim of the Green Revolution was to avert a 'red' revolution in Asia. In this context, the emphasis on a Green Revolution 'signal[ed] like a flag, that social change was not necessary, since the technical means in agriculture (evoked by "green") alone were supposed to solve the problem of hunger' (Spitz, 1987:56). Thus, framing of the problem to be solved as one of production, not income, deftly steered the debate away from socio-economic concerns and towards technical ones; while the identification of a solution embedded 'in the seed', with built in scalability, preempted discussion of issues of distribution and inequality (Anderson et al, 1991; Cullather, 2004).

The socio-economic and environmental consequences of the Green Revolution have been extensively debated over the years (Pearse, 1980; Griffin, 1979; Glaeser, 1987; Lipton \& Longhurst, 1989; David \& Otsuka, 1993). Moreover, while primarily a public sector effort, there is no doubt that the widespread adoption, during the Green Revolution, of 'improved' seeds, chemical inputs and farm mechanisation served to open up developing country agriculture to capitalist investment (Cullather, 2004; Morvaridi, 2012b). In this context, the role of private philanthropy was understood as an intermediary one, positioned between the 'public' and 'private', acting to 'correct for' the market and ensure the new technologies qualified as 'public goods'.

In contrast, contemporary 'philanthrocapitalists,' such as the Bill and Melinda Gates Foundation (BMGF), see their role as bringing business principles to the development sector; 'extending leverage' through links with the private sector and so achieving 'impact at scale' (Edwards 2008). Rather than 'correct for' the market, they seek to 'connect to' the market (Brooks et al, 2009a; Brooks, 2011). This paper illustrates this transition from scientific philanthropy to philanthrocapitalism through two case studies: firstly, the two decades-long 'Golden Rice' project which has bridged the two eras; and secondly, a more recent programme aiming to develop and commercialise drought tolerant maize varieties in Sub Saharan Africa, whose design has drawn selectively on these early lessons.

Comparison of the 'logic model' (Frumkin 2006) informing these ventures highlights both disjunctures and continuities in terms of the theory of change and notions of scale and leverage that have informed their design. Firstly, the belief in the inherent scalability of a solution based on genetics-led crop improvement remains unshaken, despite a professed shift in focus to the needs of smallholder farmers. Secondly, a theory of change combines the familiar 'technical fix' with a 
'market fix' that would integrate smallholder farmers into commercial value chains. Thirdly, this change model relies on a transformed understanding of leverage as 'connecting to' rather than 'correcting for' the market in the provision of public goods.

Fourthly, a focus on institutional challenges and innovations highlights as a key element of continuity the inseparability of questions of philanthropic 'giving' and capitalist accumulation. In each of the initiatives explored in this paper, novel institutions developed for technology transfer and development assistance have served to prepare the ground for future accumulation in ways that may not be immediately obvious. In this context, these initiatives can be seen as institutional experiments that are already shifting debates about genetically modified ('GM') crops and their regulation - reframing questions of 'access' to technology in terms that valorize corporate 'donors' of proprietary technologies and bolstering the case for industry-friendly technology regulatory frameworks. Meanwhile an emphasis on silver bullet solutions and institutions that 'connect to the market' is diverting attention away from the multiplicity of alternative approaches that respond to the conditions, needs and practices that constitute smallholder agriculture in diverse locations.

\section{Bridging 'old' and 'new' Philanthropy: the case of Golden Rice}

In the early 1990s, scientists based at the Swiss Federal Institute of Technology (ETH) secured funding from the International Program on Rice Biotechnology (IPRB), a programme established in the 1980s by the Rockefeller Foundation to support the development of biotechnology capacity and applications oriented to developing country needs and priorities (Evenson et al, 1996). While the majority of projects funded addressed, either directly or indirectly, the problem of yield, funding was also allocated to a project that sought to 'genetically engineer the pro-vitamin A pathway into the rice endosperm' (Potrykus, 2001). The justification for funding this research was that, while the likelihood of success was considered to be low, the potential benefits in public health terms would be significant, given that vitamin A deficiency was a priority concern for the international nutrition community (Mason et al, 2001). When the scientists achieved the transformation in their laboratory in Zurich in 1999, on the eve of the closure of the IPRB, the project was hailed as the IPRB's 'greatest achievement' (Normile, 1999).

In 2001 a lead article in Time magazine announced the discovery of what had become known as 'Golden Rice' with the assertion: 'this rice could save a million kids a year' (Nash, 2001). The article confirmed the project's status as 'poster child' in an increasingly polarised GM crop debate, as claims made for a technology still in the lab attracted contestation and controversy (Nestle, 2001, BIOTHAI et al, 2001). A significant and less well understood dimension of the controversy was the 
transfer of the outputs of what had been public sector research, financed by governmental as well as philanthropic funding, to a private company, Syngenta, in exchange for assistance in negotiating unanticipated intellectual property restrictions; intensifying suspicion that Golden Rice would serve as a 'Trojan Horse' to gain public acceptance of GM crops more generally (Pollan, 2001). The inventors and their new sponsors, on the other hand, drew attention to the creation of a 'new type of public private partnership,' which would allow the free transfer of proprietary technology to public research institutions in developing countries able to adapt and disseminate the new, nutrient-dense varieties to resource poor farmers (Potrykus, 2001).

In 2002, Golden Rice materials were transferred to the International Rice Research Institute (IRRI) ${ }^{3}$ in the Philippines. A 'Humanitarian Board', initially comprising the Golden Rice inventors and donors and a Syngenta representative, had issued a 'humanitarian license' enabling IRRI and selected regional partners to begin the time consuming, and far less glamorous task of 'backcrossing' the Golden Rice 'trait' into indica varieties, using conventional plant breeding techniques. Ingo Potrykus and his colleagues at ETH had succeeded in transferring a gene containing betacarotene, a precursor of vitamin A, into a japonica rice variety, which grows in temperate zones. Populations targeted by the Golden Rice project live in tropical environments, where indica varieties predominate. In parallel with this adaptive research at IRRI, scientists at Syngenta continued to work on japonica materials, and were twice successful in increasing the beta-carotene level in the grain (as well as removing the selectable marker gene) - prompting IRRI and its partners to discard the results of earlier adaptive research and start again with the newly donated japonica materials. The research continued, in a far from linear fashion, over several years, until, in 2008, IRRI scientists stablised germplasm ready for open field trials and preliminary nutrition studies (Brooks, 2010; Al-Babili \& Beyer, 2005).

The BMGF began co-funding Golden Rice research in 2003, channeling funds through two major new initiatives, the CGIAR HarvestPlus Biofortification Program (HarvestPlus, 2004) and, under its 'Grand Challenges for Global Health' initiative, the 'ProVitaMinRice' Consortium - created to extend Golden Rice research to the development of rice enriched with multiple nutrients (BMGF, 2003). In their design, both programmes emphasised a genetic-led research approach which, it was envisaged, would have a large scale impact on micronutrient malnutrition across the developing world - part of a centralised vision that equated biofortification (an umbrella term for micronutrient-dense staple crops) with water fluoration: 'The [required nutrients] will get into the food system much like we put fluoride in the water system. It will be invisible, but it will be there to

\footnotetext{
${ }^{3}$ IRRI is the CGIAR international crop research centre whose mandate focuses on rice research.
} 
increase intakes' (Bouis 2004). Here elements of continuity can be found with the scientific philanthropy of Carnegie, Rockefeller and Ford, in the attraction of 'silver bullet' solutions technical, generic and inherently scalable - repackaged in the context of a contemporary target culture as a 'Grand Challenge' (Brooks et al, 2009a). Despite the lack of evidence at the time as to the effectiveness, or even the efficacy, of biofortification, the BMGF took a 'leap of faith' in committing substantial funding to a suite of biofortification initiatives, including Golden Rice (Brooks, 2010).

In 2011 the BMGF announced nearly \$20 million in new grants for biofortification projects; including funds to 'help in the development, testing and marketing of Golden Rice' (Nayer 2011). Since then, the Philippines Rice Research Institute (PhilRice), in cooperation with IRRI, has carried out two seasons of field trials, which concluded in early 2013 (PhilRice, 2013). Meanwhile, the findings of a nutrition study carried out with a group of healthy children in controlled conditions have been published (Tang et al., 2012) ${ }^{4}$. With the field trials and preliminary nutrition studies completed, community nutrition studies to ascertain whether Golden Rice will indeed prove effective as an antidote to vitamin A deficiency in malnourished populations in 'real world' settings are now underway; overseen by a new project partner, Helen Keller International. These studies, together with further post harvest research and preparation for regulatory assessment, "will take two years or more', according to a recent clarifying statement from IRRI (IRRI 2013).

Nevertheless, a consistent theme running through Golden Rice project communications has been an emphasis on institutional constraints and achievements, which has diverted attention from the faltering progress of the research itself (Brooks, 2010). The celebration of the project as a 'new type of public private partnership' through which the inventors had secured assistance from Syngenta in negotiating the 'frightening number' of patents and material transfer agreements (MTAs) (Potrykus, 2001) is a case in point. In fact, this solution had been one of a range of options set out in a Rockefeller Foundation-commissioned 'freedom to operate' study which, interestingly, had drawn attention to the inapplicability of many of the patents in the countries targeted by the project (Kryder et al., 2000; Hindmarsh and Hindmarsh, 2002; Brooks, 2010). In the event, settlement on the 'humanitarian use' option preempted exploration of these alternative options. The agreement generated series of new institutions; a 'humanitarian license', to allow the technology to be 'donated' by Syngenta, free of charge, to public research institutions and ultimately to farmers whose income was below a set level ( $\$ 10,000$ per annum); a 'Humanitarian Board' to oversee the use of the license; and a 'Golden Rice Network' of public research bodies, coordinated by IRRI (as

\footnotetext{
${ }^{4}$ Nevertheless, ethical concerns surrounding the study have generated further controversy (Enserink, M. (2013)).
} 
'technology holder') and including several of its 'traditional' regional partners, though on markedly different terms (Brooks, 2010).

Juxtaposed against the success story of the institutionalisation of the 'humanitarian use' principle was a more negative story about the regulatory hurdles standing between the Golden Rice technology and its projected beneficiaries. Here the Golden Rice trajectory intersected with the contested politics of biosafety regulation, particularly in the developing world, where it has become the focus of broader public debates about GM technology and development - largely because it is one of the few remaining spaces where such debate can still take place (Van Zwanenberg et al, 2011). In this context, Golden Rice has been afforded a very different, 'virtual' identity in policy and public discourse, as a potent symbol of the thwarted promise of GM crops (Brooks, 2013). In contrast to its messy material reality as experimental material in the laboratory and greenhouse, Golden Rice was reconstructed as a proven technology and all but finished product, which, but for unnecessarily burdensome regulation and irrational opposition, would already be in farmers' fields and saving lives (Potrykus, 2010 \& 2012; see also McVie, 2013, Taverne, 2007). Some have even have gone so far as to state that regulatory 'hurdles' slowing down the dissemination of a lifesaving technology constitute 'a crime against humanity' (Potrykus, 2010: 466).

The dynamics and consequences, for downstream 'users', of a complex research trajectory, in which a range of scientific and policy uncertainties have been shielded from view, have been explored in depth elsewhere (Brooks, 2010, 2011 \& 2013). Crucially, fundamental questions regarding the efficacy and safety of Golden Rice, both as a commercial rice variety and solution to vitamin A deficiency have yet to be unanswered. Nonetheless, as an institutional experiment in conditional intellectual property transfer, the institutional arrangements surrounding the Golden Rice project, which embed a particular model of technology transfer, have served as a template for the development of a more refined, and, thus far, less contentious partnership - the Nairobi-based African Agricultural Technology Foundation (AATF).

\section{Model partnerships?}

Drought tolerant maize is the Holy Grail for agricultural research in Sub Saharan Africa (Brooks et al, 2009b). Breeding maize varieties for drought conditions has been a research priority in Sub Saharan Africa for many years, beginning with early maturing 'drought escaping' varieties developed in the 1960s and 1970s (Heisey \& Edmeades, 1999). From the 1980s onwards, the development of drought tolerant (as opposed to drought escaping) varieties became a priority for the 
International Centre for Improvement of Maize and Wheat (CIMMYT) ${ }^{5}$ and in the 1990s scientists at CIMMYT's base in Zimbabwe developed a plant breeding methodology which represented an important departure from the approach - up to that point entrenched within the CGIAR - of developing elite lines in 'optimal conditions'. Researchers in CIMMYT's 'Southern African Drought and Low Soil Fertility' (SADLF) project piloted a new breeding technology for a range of 'managed stress conditions', including - but not confined to - drought conditions, under what has been referred to as 'Africa's new smallholder maize paradigm' (McCann et al, 2007). This methodology was implemented on a wider scale under the 'African Maize Stress' (AMS) project (Banziger \& Diallo, 2000); a project that was also innovative in other ways, for example in piloting the 'mother-baby' model that invited an albeit limited degree of farmer participation in technology development (de Groote \& Siambi, 2005; Sawkins et al, 2006).

In the early 2000s, two parallel research initiatives were funded by the BMGF. The first was the CGIAR-led programme 'Drought Tolerant Maize for Africa (DTMA)' and the other - headed by the newly established public private partnership, the African Agricultural Technology Foundation (AATF) - was entitled 'Water Efficient Maize for Africa (WEMA)'. Their aim was to tackle the problem of breeding maize for drought conditions. While employing the maize breeding methodology refined during the years of the SADLF and AMS projects, these new programmes differed from precursor initiatives in important ways - dispensing with the more context-sensitive and participatory aspects of the 'smallholder paradigm' that had been so positively evaluated (McCann et al, 2007). Firstly, both the DTMA and WEMA were framed as responses to the impacts of climate change on African agriculture, and focused specifically on the problem of drought, and not on the broader range of inter-related stresses and constraints faced by smallholder farmers as was formerly the case (Brooks et al, 2009b). Secondly, while precursor programmes had prioritised development of open pollinated varieties (OPVs), which allow farmers to save, exchange and replant seed from one year to the next, both DTMA and WEMA are designed around a package that includes newly developed hybrid maize varieties and commercial fertilizers. These were to be made available to farmers via a network of private providers, or agro-dealers, now cast as the de facto extension service in a model promoted under Africa's new 'Green Revolution' - which was also the recipient of substantial funding from the BMGF (Odame \& Muange, 2011). In this case, it was envisaged that a model, designed with Kenya's high potential maize growing zones in Western Kenya and the Rift Valley in mind, would 'trickle down' to the precarious mixed farming systems found in drought-prone areas to the east of the country. At the same time, the participatory element in the earlier programmes was eclipsed by a recasting of 'the farmer' as a consumer of

\footnotetext{
${ }^{5}$ CIMMYT is the CGIAR international crop research centre whose mandate focuses on maize and wheat research.
} 
predetermined technologies rather than as a partner in participatory technology development (Brooks et al, 2009b; Scoones and Thompson, 2011; cf. Ashby, 2009).

The two programmes can be also contrasted with each other in important ways. Firstly, the DTMA programme is, as mentioned earlier, a public initiative, although (as in the case of HarvestPlus) the CGIAR centres co-ordinating the programme act as brokers in a research consortium that includes both public and private sector actors. The WEMA initiative, on the other hand, is headed by AATF, a public private partnership whose raison d'etre is to facilitate transfer of patented technologies and whose design owes much to lessons learned from institutional innovations around the Golden Rice project (Interview, Golden Rice Humanitarian Board member, 29 May 2006). Secondly, while DTMA (in common with HarvestPlus) emphasises conventional plant breeding, WEMA follows the example of the Golden Rice project in securing patented, transgenic materials 'free of charge' from a private company, Monsanto, for back-crossing into locally developed hybrid varieties. Interestingly, and again in common with HarvestPlus and Golden Rice, the DTMA and WEMA programmes are separate and distinct in theory but, in practice, intimately connected in multiple ways (see Brooks, 2010 and Brooks et al, 2009b for more extended discussion of these dynamics).

Thus far WEMA (and the AATF) has avoided the controversy courted by the Golden Rice project. Firstly, the organisational image could not be more different. AATF presents itself very clearly as an African institution. Criticisms of the role of corporate interests and control, so heightened in Golden Rice debates, have been more muted, while managers of both WEMA and DTMA have been careful to manage expectations about when technologies can be expected to emerge from the pipeline (Brooks et al, 2009b). Nevertheless, the virtual identity of drought tolerant maize as a symbol of technological promise (cf. Glover, 2010) has made itself felt in debates surrounding the design of biosafety regulatory systems in Sub Saharan Africa. In this case, the use of WEMA project communications to advocate 'science-based' - read more permissive - biosafety regulation (WEMA, n.d.) suggests this is a role that has passed seamlessly from Golden Rice to the WEMA project. As concerns about the effects of climate change on African agriculture continue to escalate (Thornton et al, 2011; Vermeulen et al, 2011), the promise of drought tolerant maize in maizecentred farming regions may, in the long run, prove to be a powerful lever in shaping regulatory instruments that are currently under development. Meanwhile, projects such as WEMA serve as an opportunity for continued experimentation and learning, by various actors, including the life sciences industry, in the conditional transfer of intellectual property rights and benefits. 


\section{'Win-win solutions' - or winners and losers?}

Debates about private philanthropy often separate the giving of money from the making of it. Drawing upon two examples of philanthropy in action, this paper has shown that the dividing line is not so easily drawn. Rather, the ways in which capital accumulation and philanthropy are interwoven is not always obvious. One of the advantages that private philanthropists have over other international development actors, governmental and nongovernmental, is their independence from short term incentives and pressures. Private foundations are uniquely able to take a long-term view and take risks. Decisions by the Rockefeller Foundation to found IRRI, the first institution of its kind (Anderson et al 1991), and to invest in the 15-year IPRB, which would lay the foundations for a global biotechnology research capacity in rice, are clear examples of this. Similarly, in the contemporary era, the BMGF has taken decisions to support, not only the development of new technologies, but also 'new types of public private partnership' - as exemplified by the Golden Rice project and AATF. Similarly, the BMGF has taken decisions to support, not only the development of new technologies, but also new types of public-private partnership. These partnerships can be seen as institutional experiments that are already shifting debates about GM crops and their regulation: reframing questions of 'access' to technology in terms that valorise the technology 'donor'; and advocating regulatory systems that 'enable' more rapid approval of new technologies. Meanwhile the single-minded pursuit of technological and institutional solutions that connect to the market - both 'upstream' in top-down modes of technology transfer, and 'downstream' in privatised seed delivery channels - detracts from alternative approaches more responsive to local realities.

The Asian Green Revolution, launched with the support of the Rockefeller and Ford Foundations in the 1960s, was a public sector effort that nevertheless played a key role in opening up developing country agriculture to capitalist investment. Today, global attention is focused on an imperative to accelerate agricultural production in Africa. A 'New Alliance for Food Security and Nutrition', a major new US-led initiative which aims to 'help lift 50 million people in Sub Saharan Africa out of poverty in the next 10 years by supporting agricultural development' was recently launched (USAID, n.d.), giving a key role to agri-business corporations. These developments, alongside an increasingly high profile presence of the BMGF and other philanthrocapitalists in development debates are blurring the boundary between development aid and private investment yet further. It is important, therefore, to look beyond the 'win-win' rhetoric that surrounds the 'new philanthropy' and its defining role in global development: to critically examine the design and operation of philanthropic ventures in practice and ask who will be the winners and losers in the long term. 


\begin{abstract}
About the author
Sally Brooks is a social researcher with interests in international development, technological change in agriculture and food policy, based in York, UK. In recent years she has worked as a researcher and tutor at the Institute of Development Studies (IDS) and STEPS Centre at the University of Sussex and the Department of Social Policy at the University of York; and is currently research associate on a component of the BBSRC-funded 'Sustainable Crop Production for International Development' Project led by the School of International Development (DEV) at the University of East Anglia and John Innes Centre. Previously she worked with development NGOs in Southeast Asia for several years. She is author of 'Rice Biofortification: Lessons for Global Science and Development' (Earthscan: 2010). More information about her work can be found at http://www.sallybrooksconsulting.com/publications/
\end{abstract}




\section{References}

Al-Babili, S. \& Beyer, P. (2005) 'Golden Rice - five years on the road - five years to go?', Trends in Plant Science, vol 10, pp 565-573.

Anderson, R. S. Levy, E. \& Morrison, B. M. (1991) Rice Science and Development Politics: Research Strategies and IRRI's Technologies Confront Asian Diversity (1950-1980), Oxford: Clarendon Press.

Ashby, J. A. (2009) 'Fostering Farmer First Methodological Innovation: Organisational Learning and Change in International Agricultural Research', in Scoones, I. \& Thompson, J. (eds) Farmer First Revisited: Innovation for Agricultural Research and Development. London: Practical Action Publishing.

Banziger, M. \& Diallo, A. O. (2000) 'Stress-tolerant Maize for Farmers in Sub-Saharan Africa', Maize Research Highlights 1999-2000, Mexico: CIMMYT.

BIOTHAI, CEDAC (Cambodia), DRCSC (India), GRAIN, MASIPAG (Philippines), PANIndonesia \& UBINIG (Bangladesh) (2001), 'Grains of Delusion: Golden Rice Seen from the Ground', Los Banos, Philippines: MASIPAG.

BMGF (2003) Grand Challenge \#9: Engineering Rice for High Beta Carotene, Vitamin E and Enhanced Fe and Zn Bioavailability,

http://www.grandchallenges.org/ImproveNutrition/Challenges/NutrientRichPlants/Pages/Rice .aspx\#ResearchObjectives.

Bouis, H. (2004) 'Hidden Hunger: The Role of Nutrition, Fortification and Biofortification', World Food Prize International Symposium: From Asia to Africa: Rice, Biofortification and Enhanced Nutrition, 14-15 October, Des Moines, Iowa.

Brooks, S. (2010) Rice Biofortification: Lessons for Global Science and Development, London: Earthscan.

Brooks, S. (2011) 'Is international agricultural research a global public good? The case of rice biofortification', Journal of Peasant Studies, vol 38, pp 67 - 80.

Brooks, S. (2013) 'Biofortification: lessons from the Golden Rice project', Food Chain, vol 3, pp 77-88.

Brooks, S. Leach, M.. Lucas, H. \& Millstone, E. (2009a) Silver Bullets, Grand Challenges and the New Philanthropy, STEPS Working Paper 24, Brighton: STEPS Centre.

Brooks, S. Thompson, J. Odame, H. Kibaara, B. Nderitu, S. Karin, F. \& Millstone, E. (2009b) 'Environmental Change and Maize Innovation in Kenya: Exploring Pathways In and Out of Maize', STEPS Working Paper 36, Brighton: STEPS Centre.

Carnegie, A. (1889) 'Gospel of Wealth', North American Review, CCCXCI.

Cullather, N. (2004) 'Miracles of Modernisation: The Green Revolution and the Apotheosis of Technology', Diplomatic History, vol 28, pp 227-254.

David, C. C. \& Otsuka, K. (eds) (1993) Modern Rice Technology and Income Distribution in Asia, Manila: IRRI.

de Groote, H. \& Siambi, M. (2005) 'Comparing and Integrating Farmers' and Breeders' Evaluations of Maize Varieties in East Africa', in Gonsalves, J. Becker, T. Braun, A. Campilan, D.

Chavez, H. D. Fajber, E. Kapiriri, M. Rivaca-Caminade, J. \& Vernooy, R. (eds) Participatory Research and Development for Sustainable Agriculture and Natural Resource Management:

A Sourcebook. Volume 3: DOING Participatory Research and Development. CIPUPWARD/IDRC.

Edwards, M. (2008) Just Another Emperor? The Myths and Realities of Philanthrocapitalism, Demos and The Young Foundation.

Enserink, M. (2013) Golden Rice Not So Golden for Tufts, Science Insider, Science/AAAS, http://news.sciencemag.org/asiapacific/2013/09/golden-rice-not-so-golden-tufts [accessed 1 November 2013].

Evenson, R. E. Herdt, R. W. \& Hossain, M. (1996) Rice Research in Asia: Progress and priorities, Wallingford: CAB International. 
Frumkin, P. (2006) Strategic Giving: The art and science of philanthropy, Chicago: University of Chicago Press.

Glaeser, B. (1987) 'Agriculture between the Green Revolution and Eco-development: Which way to go?', in Glaeser, B. (ed) The Green Revolution Revisited: Critique and Alternatives, London: Allen and Unwin.

Glover, D. (2010) 'Exploring the Resilience of Bt Cotton's 'Pro Poor Success Story', Development and Change, vol 41, pp 955-981.

Griffin, K. (1979) The Political Economy of Agrarian Change: An Essay on the Green Revolution, New York: Macmillan Press.

HarvestPlus (2004) Breeding Crops for Better Nutrition: Harnessing Agricultural Technology to Improve Micronutrient Deficiencies, Washington DC: International Food Policy Research Institute.

Heisey, P. W. \& Edmeades, G. O. (1999) 'Maize Production in Drought-Stressed Environments: Technical Options and Research Resource Allocations', in World Maize Facts and Trends 1997/8; Maize Production in Drought-Stressed Environments: Technical Options and Research Resource Allocations, Part 1, Mexico: CIMMYT.

Hindmarsh, S. \& Hindmarsh, R. (2002) 'Laying the Molecular Foundations of GM Rice Across Asia', Resource Book Volume 1. Penang: Malaysia Pesticide Action Network.

IRRI. 2013. Clarifying recent news about Golden Rice [Online]. Manila: International Rice Research Institute. Available: http://www.irri.org/index.php?option=com_k2\&view=item\&id=12483 [Accessed 14 March 2013].

Kryder, R. D. Kowalski, S. P. \& Krattiger, A. F. (2000) The Intellectual and Technical Property Components of pro-Vitamin A Rice (Golden Rice): A Preliminary Freedom-To-Operate Review, New York: International Service for the Acquisition of Agri-biotech Applications (ISAAA).

Lipton, M. \& Longhurst, R. (1989) New Seeds and Poor People, London: Unwin Hyman.

Mason, J. B. Lotfi, M. Dalmiya, N. Sethuraman, K. \& Deitchler, M. (2001) The Micronutrient Report: Current Progress and Trends in the Control of Vitamin A, Iodine and Iron Deficiencies, Ottawa: The Micronutrient Initiative/ International Development Research Centre.

McCann, J. C. Dalton, T. J. \& Mekuria, M. (2007) 'Breeding for Africa's new smallholder maize paradigm', International Journal of Agricultural Sustainability, vol 4, pp 99-107.

McVie, R. (2013) 'After 30 years, is a GM food breakthrough finally here?' The Observer, Saturday 2 February.

Morvaridi, B. (2012a) 'Capitalist Philanthropy and Hegemonic Partnerships', Third World Quarterly, vol 33, pp 1191-1210.

Morvaridi, B. (2012b) 'Capitalist Philanthropy and the New Green Revolution for Food Security', International Journal of Sociology of Agriculture and Food, vol 19, pp 243-256.

Nash, M. (2001) 'Grains of Hope', Time Magazine, Monday 5th February, pp 38-46.

Nayar, A (2011) Grants aim to fight malnutrition Nature News, Published online 14 April 2011, doi:10.1038/news.2011.233

Nestle, M. (2001) 'Genetically Engineered "Golden Rice" is Unlikely to Overcome Vitamin A Deficiency; Response by Ingo Potrykus', Journal of the American Diabetic Association, vol 101, pp 289-290.

Normile, D. (1999) 'Rice Biotechnology: Rockerfeller to End Network After 15 Years of Success', Science, vol 286, pp 1468-1469.

Odame, H. \& Muange, E. (2011) 'Can Agro-dealers Deliver the Green Revolution in Kenya?' IDS Bulletin, vol 42, pp 78-89.

Pearse, A. (1980) Seeds of Plenty, Seeds of Want: Social and Economic Implications of the Green Revolution, Oxford: Clarendon Press. 
Perkins, J. H. (1997) Geopolitics and the Green Revolution: Wheat, Genes and the Cold War, Oxford: Oxford University Press.

PhilRice. 2013. Two seasons of Golden Rice trials in Phl concluded [Online]. Neuva Ecija: Philippines Rice Research Institute. Available: http://www.philrice.gov.ph/?page=resources\&page2=news\&id=211 [Accessed 14 March 2013].

Pollan, M. (2001) 'The Great Yellow Hype', The New York Times Magazine, 4 March.

Potrykus, I. (2001) 'Golden Rice and Beyond', Plant Physiology, vol 125, pp 1157-1161.

Potrykus, I. (2010) 'Lessons from the Humanitarian Golden Rice project: regulation prevents development of public good genetically engineered crop products', New Biotechnology, vol 27, pp 466-472.

Potrykus, I. (2012) 'Golden Rice, a GMO-product for public good, and the consequences of GEregulation', Journal of Plant Biochemistry and Biotechnology, vol?, pp 1-8.

Sawkins, M. C. DeMeyer, J. \& Ribaut, J. M. (2006) 'Drought Adaptation in Maize', in: Ribaut, J. M. (ed) Drought Adaptation in Cereals. New York: Haworth.

Scoones, I. \& Thompson, J. (2011) 'The politics of seed in Africa's green revolution: Alternative narratives and competing pathways', IDS Bulletin, vol 42, pp 1-23.

Smith, R. (2009) 'The emergence of vitamins as bio-political objects during World War I', Studies in History and Philosophy of Science Part C: Studies in History and Philosophy of Biological and Biomedical Sciences, vol 40, pp 179-189.

Spitz, P. (1987) 'The Green Revolution Re-examined in India', in Glaeser, B. (ed) The Green Revolution Revisited: Critique and Alternatives, London: Allen and Unwin.

Tang, G., Hu, Y., Yin, S., Wang, Y., Dallal, G. E., Grusak, M. A. \& Russell, R. M. 2012. BetaCarotene in Golden Rice is as good as beta-carotene in oil at providing vitamin A to children. The American Journal of Clinical Nutrition, 96, 658-664. , doi: 10.3945/ ajcn.111.030775

Taverne, R. (2007) 'The real GM food scandal', Prospect, vol 140, pp 24-27.

Thornton, P. K. Jones, P. G. Eriksen, P. J. \& Challinor, A. J. (2011) 'Agriculture and food systems in sub-Saharan Africa in a $4^{\circ} \mathrm{C}+$ world', Philosophical Transactions of the Royal Society, vol 369, pp 117-136.

USAID (n.d.) The New Alliance for Food Security and Nutrition. http://www.usaid.gov/unga/newalliance [accessed 25 September 2013]

Van Zwanenberg, P. Ely, A. \& Smith, A. (2011) Regulating technology: International harmonization and local realities, London: Earthscan.

Vermeulen, S. J. Aggarwal, P. Ainslie, A. Angelone, C. Campbell, B. M. Challinor, A. Hansen, J. W. Ingram, J. Jarvis, A. \& Kristjanson, P. (2011) 'Options for support to agriculture and food security under climate change, Environmental Science \& Policy, vol 15, no. 1 pp 136-144.

WEMA, n.d. Combining Breeding and Biotechnology to Develop Water Efficient Maize for Africa (WEMA). Concept Note, African Agricultural Technology Foundation: Nairobi.

http://www.aatf-africa.org/UserFiles/File/Wema-Concept-Note.pdf 


\section{Recent papers in the SPRU Working Paper Series:}

SWPS 2013-01. Gabriele Pellegrino and Maria Savona. September 2013. "Is money all? Financing versus knowledge and demand constraints to innovations".

SWPS 2013-02. Adrian Smith and Sabine Hielscher. September 2013. “Grassroots digital fabrication and makerspaces: reconfiguring, relocating and recalibrating innovation".

SWPS 2013-03. Paul Nightingale and Alex Coad. September 2013. "Muppets and gazelles: political and methodological biases in entrepreneurship research".

SWPS 2013-04. Alberto Marzucchi and Sandro Montresor. September 2013. "The multidimensional additionality of innovation policies. A multi-level application to Italy and Spain".

SWPS 2013-05. Fulvio Castellacci. September 2013. "Institutional voids or entry barriers? Business groups, innovation and market development in emerging economies".

SWPS 2013-06. Tommaso Ciarli and Michele Di Maio. October 2013. "Theoretical arguments for industrialisation-driven growth and economic development".

SWPS 2013-07. William Lazonick, Mariana Mazzucato, and Öner Tulum. October 2013. “Apple's changing business model: what should the world's richest company do with all those profits?".

SWPS 2013-08. Phil Johnstone. October 2013. "Planning reform, rescaling, and the construction of the post-political: The case of The Planning Act 2008 and nuclear power consultation in the UK".

SWPS 2013-09. Mariana Mazzucato and Alan Shipman. October 2013. "Accounting for productive investment and value creation".

SWPS 2013-10. Anders Bornhäll, Sven-Olov Daunfeldt, and Niklas Rudholm. October 2013.

"Sleeping Gazelles: High profits but no growth".

SWPS 2013-11. Alex Coad and Christina Guenther. November 2013. "Processes of firm growth and diversification: theory and evidence".

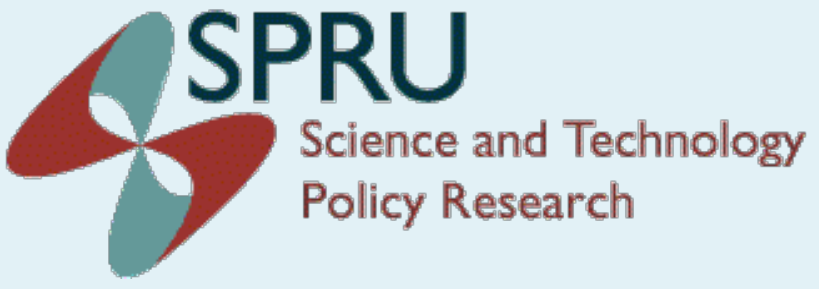

SPRU

Science and Technology Policy Research

University of Sussex

Falmer, Brighton, BN1 9SL, UK

www.sussex.ac.uk/spru 